\title{
Analisis Penggunaan Ragam Bahasa Indonesia Siswa dalam Komunikasi Verbal
}

\author{
Kd Dana Handika ${ }^{1}$, I Km Sudarma ${ }^{2}$, I Nym Murda ${ }^{3}$ \\ ${ }^{13}$ Jurusan Pendidikan Guru Sekolah Dasar, ${ }^{2} J u r u s a n$ Teknologi Pendidikan \\ Fakultas IImu Pendidikan, Universitas Pendidikan Ganesha \\ Singaraja, Indonesia \\ e-mail: danahandika22@yahoo.com
}

\begin{abstract}
Abstrak
Penelitian ini bertujuan untuk mendeskripsikan identifikasi ragam bahasa Indonesia siswa dalam komunikasi verbal, pola interaksi siswa dalam pembelajaran melalui penggunaan ragam bahasa, dan dampak pola interaksi siswa dalam penggunaan ragam bahasa terhadap hasil belajar siswa SD Negeri 4 Pedawa. Jenis penelitian ini menggunakan rancangan deskriptif kualitatif. Populasi penelitian ini adalah siswa SD Negeri 4 Pedawa yang berjumlah 84 siswa. Metode pengumpulan data yang digunakan yaitu observasi, rekam, dan wawancara. Teknik analisis data yang digunakan yaitu analisis deskriptif kuantitatif dan analisis deskriptif kualitatif dalam proses mendapatkan data penelitian dan mendeskripsikan dengan kata-kata tertulis. Hasil penelitian menunjukan bahwa di dalam komunikasi verbal terdapat ragam bahasa dari segi keformalan yang terdiri dari ragam beku yang digunakan sebanyak 9 tuturan (11\%), ragam resmi sebanyak 23 tuturan (28\%), ragam santai sebanyak 50 tuturan $(60 \%)$, dan ragam akrab sebanyak 1 tuturan (1\%). Pola interaksi yang terjadi terdiri dari komunikasi satu arah, komunikasi dua arah, dan komunikasi multi arah. Sedangkan hasil belajar siswa yang ditemukan beragam, siswa kelas I yang sudah mencapai KKM sebanyak 12 siswa (86\%), siswa kelas II yang sudah mencapai KKM sebanyak 13 siswa (93\%), siswa kelas III yang sudah mencapai KKM sebanyak 12 siswa (80\%), siswa kelas IV yang sudah mencapai KKM sebanyak 6 siswa (75\%), siswa kelas $V$ yang sudah mencapai KKM sebanyak 10 siswa (67\%), dan siswa kelas VI yang sudah mencapai KKM sebanyak 14 siswa (82\%).
\end{abstract}

Kata Kunci: Hasil Belajar Siswa, Pola Interaksi, Ragam Bahasa

\begin{abstract}
The research aim to describe identification of student's language variation in verbal communication, patterns of student interaction in learning through the employing of various languages, and the impact of interaction patterns of students in the employing of language variety of student's learning outcomes SD Negeri 4 Pedawa. This type of research by using qualitative descriptive design. The research population was students of SD Negeri 4 Pedawa, that consists of 84 students. Data collection methods used are observation, record, and interview. The data were analyzed by using the procedure of descriptive quantitative data analysis and qualitative data analysis in the process of obtaining research data and describe with written words. The result of the research shows that in verbal communication there is a variety of languages in terms of formality which consists of a frozen style are used as much as 9 speeches (11\%), formal style of 23 speeches (28\%), casual style of 50 speeches (60\%), and intimate style of 1 speeches (1\%). The pattern of interaction that occurs consists of direct communication, interaction communication, and transaction communication. While the student learning outcomes found diverse, first grade students who have reached KKM as many as 12 students (86\%), second grade students who have reached KKM as many as 13 students (93\%), third grade students who have reached KKM as many as 12 students (80\%), fourth grade students who have reached KKM as many as 6 students (75\%), fifth grade students who have reached KKM as many as 10 students (67\%), and sixth grade students who have reached KKM as many as 14 students (82\%).
\end{abstract}

Keywords: Student Learning Outcomes, Interaction Patterns, Language Variety 


\section{Pendahuluan}

Bahasa merupakan suatu budaya manusia yang mempunyai nilai sangat tinggi, karena dengan bahasa manusia akan dapat menjalankan kelangsungan hidupnya dengan baik dan teratur. Bisa dikatakan bahwa bahasa merupakan salah satu kebutuhan primer yang bisa berperan sebagai pengatur sirkulasi kelanjutan hidup.

Apriastuti (2017) menyatakan bahasa merupakan alat utama untuk berkomunikasi dalam kehidupan manusia, dengan bahasa manusia mampu mengungkapkan pikiran dan perasaannya kepada orang lain.

Sudaryati (2018) menyatakan bahasa dikatakan bervariasi atau beragam, karena bahasa digunakan penutur yang heterogen yang mempunyai kebiasaan dan latar belakang sosial yang berbeda-beda. Penggunaan ragam atau variasi bahasa bisa terjadi dimana saja, salah satu contoh yaitu di Indonesia yang memiliki banyak suku dan budaya.

Penggunaan bahasa yang berbeda-beda dikenal dengan sebutan ragam bahasa (Kurniawati, 2009). Penggunaan ragam bahasa di Indonesia bisa dikatakan tidak sedikit jumlahnya, hal ini bisa dibuktikan dengan adanya berbagai macam suku, ras, dan budaya yang ada di Indonesia. Selain itu, kaum muda yang dengan kreativitasnya selalu saja berhasil menemukan bentuk-bentuk kebahasaan yang sebelumnya tidak pernah digunakan dan kemudian memunculkan bahasa baru. Penggunaan ragam bahasa yang sering dijumpai selain dalam lingkungan masyarakat yaitu di lingkungan sekolah.

Sekolah merupakan tempat proses belajar mengajar terjadi antara guru dan siswa, sehingga tidak dapat dihindari adanya suatu interaksi dalam kegiatan pembelajaran maupun nonpembelajran. Terjadinya interaksi yang dilakukan siswa dengan guru serta siswa dengan siswa lainnya menimbulkan komunikasi secara verbal maupun nonverbal. Hartati dan Cuhariah (dalam Agustina, dkk., 2015) mengungkapkan bahwa "ada tanda khas dari seorang anak ketika masuk sekolah yakni anak ingin berbaur dengan masyarakat di lingkungan sekolahnya terutama anak seusianya".

Ragam bahasa juga bisa terjadi di suatu lingkungan sekolah. Hal ini disebabkan karena siswa dan guru berada dalam lingkungan formal (sekolah), sehingga bahasa yang digunakan harus bahasa formal. Namun kenyataannya, siswa kerap kali menggunakan ragam bahasa santai maupun ragam bahasa akrab dalam berkomunikasi. Hal ini tidak dapat dipungkiri karena kebiasaan siswa saat berkomunikasi dengan temannya di luar sekolah menggunakan ragam bahasa santai atau ragam bahasa akrab.

Menurut Chaer dan Agustina (1995: 82) membedakan variasi bahasa yaitu dari segi penutur, segi pemakaian, segi keformalan, dan segi sarana. Namun dalam penelitian ini akan dibahasa ragam bahasa dari segi keformalannya saja. Ragam bahasa dari segi keformalannya meliputi, ragam beku (frozen), ragam resmi (formal), ragam usaha (consultative), ragam santai (casual), dan ragam bahasa akrab (intimate).

A. Ragan beku

Ragam beku adalah variasi bahasa yang paling formal, yang digunakan dalam situasisituasi khidmat, dan upacara-upacara resmi, misalnya dalam upacara kenegaraan, khotbah di mesjid, tata cara pengambilan sumpah, akte notaris, dan surat-surat keputusan. Disebut ragam beku karena pola dan kaidahnya sudah ditetapkan secara mantap, tidak boleh diubah.

B. Ragam resmi

Ragam resmi atau formal adalah variasi bahasa yang digunakan dalam pidato kenegaraan, rapat dinas, surat-menyurat dinas, ceramah keagamaan, buku-buku pelajaran, dan sebagainya. Pola dan kaidah ragam resmi sudah ditetapkan secara mantap sebagai suatu standar. Ragam resmi pada dasarnya sama dengan ragam beku atau ragam standar yang digunakan salam situasi resmi.

C. Ragam usaha

Ragam usaha adalah variasi bahasa yang lazim digunakan dalam pembicaraan biasa di sekolah, dan rapat-rapat atau pembicaraan yang berorientasi kepada hasil atau produksi. Jadi, dapat dikatakan ragam usaha ini adalah ragam bahasa yang paling operasional yang berada di antara ragam formal dan informal.

D. Ragam santai

Ragam santai adalah variasi bahasa yang digunakan dalam situasi tidak resmi untuk berbincang-bincang dengan keluarga atau teman karib pada waktu istirahat, berolahraga, berekreasi, dan sebagainya. Kosakatanya banyak dipenuhi unsur leksikal dialek dan unsur bahasa daerah. 


\section{E. Ragam akrab}

Ragam akrab adalah variasi bahasa yang biasa digunakan oleh para penutur yang hubungannya sudah akrab seperti antaranggota keluarga, atau antarteman yang sudah karib. Ragam ini ditandai dengan penggunaan bahasa yang tidak lengkap, pendek-pendek, dan dengan artikulasi yang seringkali tidak jelas.

Misalkan di sekolah, guru dan siswa adalah dua subjek yang berbeda ketika berkomunikasi dalam kegiatan pembelajaran. Guru sebagai salah satu pihak yang memiliki inisiatif lebih awal untuk penyelenggaraan kegiatan pembelajaran, sedangkan siswa atau lebih dikenal dengan istilah "peserta didik" sebagai pihak-pihak yang secara langsung ataupun tidak langsung, merasakan, mengalami dan mendapatkan manfaat dari peristiwa pembelajaran yang terjadi. Sehingga dalam pembelajaran ada yang namanya pola interaksi. Pola interaksi ini terjadi antara siswa dengan guru maupun siswa dengan siswa. Menurut Djamarah (2000: 12) ada tiga pola komunikasi antara guru dan siswa dalam proses interaksi di sekolah, yakni komunikasi sebagai aksi, komunikasi sebagai interaksi, dan komunikasi sebagai transaksi.

A. Komunikasi satu arah

Komunikasi sebagai aksi atau komunikasi satu arah menempatkan guru sebagai pemberi aksi dan siswa penerima aksi (Djamarah, 2000). Dalam hal ini mengajar dipandang sebagai kegiatan menyampaikan bahan pelajaran oleh guru atau lebih sering dikenal dengan metode ceramah.

\section{B. Komunikasi dua arah}

Komunikasi sebagai interaksi atau komunikasi dua arah guru berperan sebagai pemberi aksi atau penerima aksi, demikian pula halnya siswa bisa sebagai penerima aksi, bisa pula sebagai pemberi aksi (Djamarah, 2000). Antara guru dan siswa akan terjadi dialog di kelas maupun di luar kelas.

C. Komunikasi multi arah

Komunikasi sebagai transaksi atau komunikasi multi arah, komunikasi tidak hanya terjadi antara guru dan siswa. Siswa dituntut lebih aktif daripada guru seperti halnya guru, dapat berfungsi sebagai sumber belajar bagi siswa lain (Djamarah, 2000). Begitu juga ketika diselasela istirahat, semua siswa terlibat dalam komunikasi yang dilakukan terhadap guru seperti bergurau/bercanda.

Keterkaitan bahasa dengan komunikasi sangat erat, dalam setiap komunikasi ada dua pihak yang terlibat, yaitu pengirim pesan (sender) dan penerima (receiver) (Sumarlam, dkk., 2012).

Seperti halnya dalam dunia pendidikan yang sudah berjalan berabad-abad tak luput dari sebuah bahasa yang digunakan dalam berkomunikasi baik di sekolah maupun di luar sekolah. Dengan begitu dapat dilihat bahwa betapa pentingnya peran sebuah bahasa bagi guru dalam mendidik siswa. Sebenarnya, siswa mampu belajar dengan baik jika guru mampu menciptakan lingkungan belajar yang kondusif sehingga hasil belajar siswa memuaskan. Agar dapat tercapainya proses belajar mengajar yang baik, sebagai salah satu usaha yang dapat dilakukan adalah guru menggunakan ragam bahasa yang menarik ketika berkomunikasi sehingga siswa akan mempunyai ketertarikan dengan materi yang disampaikan oleh guru dan siswapun akan mencerna dengan baik mengenai materi yang disampaikan oleh guru tersebut.

Berdasarkan temuan dan permasalahan yang dihadapi, perlu dilakukan penelitian tentang "Analisis Penggunaan Ragam Bahasa Siswa dalam Komunikasi Verbal Di SD Negeri 4 Pedawa". Tujuan yang ingin dicapai dari penelitia ini untuk mendeskripsikan identifikasi jenis ragam bahasa siswa dalam komunikasi verbal di SD Negeri 4 Pedawa, mendeskripsikan pola interaksi siswa dengan guru dalam pembelajaran melalui penggunaan ragam bahasa, mendeskripsikan pola interaksi siswa dengan siswa dalam pembelajaran melalui penggunaan ragam bahasa, dan mendeskripsikan dampak pola interaksi siswa dalam pembelajaran melalui penggunaan ragam bahasa terhadap hasil belajar siswa.

\section{Metode}

Penelitian ini menggunakan rancangan deskriptif karena menggambarkan suatu peristiwa secara sistematis sesuai dengan apa adanya untuk memperoleh informasi mengenai keadaan saat ini (Dantes, 2012). Sesuai dengan permasalahan yang diangkat, untuk penelitian ini digunakan pendekatan kualitatif dan kuantitatif. Pendekatan kualitatif digunakan untuk menganalisis data jenis ragam bahasa siswa dalam komunikasi verbal di sekolah, pola interaksi siswa dengan siswa dalam penggunaan ragam bahasa, pola interaksi siswa dengan guru dalam penggunaan ragam bahasa, dan dampak pola interaksi siswa dalam penggunaan ragam 
bahasa terhadap hasil belajar siswa. Sedangkan pendekatan kuantitatif digunakan untuk menghitung data pemunculan jenis ragam bahasa siswa yang digunakan dan untuk menghitung pemunculan hasil belajar siswa yang berhasil diperoleh. Pemunculan hasil belajar yang dimaksud adalah keberhasilan siswa yang sudah mencapai KKM dan siswa yang belum mencapai KKM.

Adapun prosedur penelitian yang dilakukan dalam penelitian deskriptif ini meliputi: (1) pernyataan masalah, peneliti harus memulai dengan pernyataan jelas mengenai masalah yang hendak diteliti, (2) identifikasi informasi yang perlu untuk pemecahan masalah, (3) pemilihan atau pengembangan instrument untuk pengumpulan data angket, daftar wawancara, tes dan berbagai bentuk skala merupakan instrument yang paling sering digunakan dalam penelitian deskriptif, (4) identifikasi populasi dan penentuan prosedur sampling, (5) penyusunan rencana prosedur untuk pengumpulan data, (6) pengumpalan data, (7) analisis data, dan (8) persiapan laporan (Dantes, 2012).

Subjek dalam penelitian ini adalah siswa kelas I s.d VI di SD Negeri 4 Pedawa yang berjumlah 84 siswa. Penelitian yang dilakukan, dengan meneliti seluruh subjek penelitian (populasi penelitian). Karena meneliti seluruh subjek penelitian (populasi penelitian), maka pada penelitian ini menggunakan teknik sensus/pengamatan lengkap (complete enumeration).

Penelitian ini menggunakan teknik pengumpulan data dengan metode observasi, teknik rekam, dan wawancara. Teknik analisis yang digunakan adalah analisis deskriptif kuantitatif yang digunakan untuk menganalisis pemunculan jenis ragam bahasa siswa dalam komunikasi verbal dan untuk untuk menghitung persentase hasil belajar siswa yang berhasil diperoleh. Persentase yang dimaksud adalah keberhasilan siswa mencapai KKM dan siswa yang belum mencapai KKM. Dasar yang digunakan dalam menentukan pemunculan jenis ragam bahasa siswa secara kuantitatif adalah jumlah tuturan siswa. Untuk mencari persentase dalam penelitian ini digunakan teknik distribusi frekuensi. Perhitungan data dengan distribusi frekuensi ini dapat dilakukan dengan menghitung frekuensi data tersebut kemudian dipersentasekan.

Frekuensi tersebut juga dapat dilihat penyebaran persentasenya, yang oleh kebanyakan orang dikenal dengan frekuensi relatif. Untuk menghitung sebaran persentase dari frekuensi tersebut, dapat digunakan rumus:

$$
\mathrm{N}=\frac{f x}{N} \times 100 \%
$$

Analisis deskriptif kualitatif digunakan untuk menganalisis identifikasi ragam bahasa siswa dalam komunikasi verbal di sekolah dasar, pola interaksi siswa dengan siswa dalam pembelajaran melalui penggunaan ragam bahasa, pola interaksi siswa dengan guru dalam pembelajaran melalui penggunaan ragam bahasa, dan dampak pola interaksi siswa dalam pembelajaran melalui penggunaan ragam bahasa terhadap hasil belajar siswa. Pengumpulan data pada penelitian ini menggunakan teknik perekaman. Oleh karena itu, pengelompokan dan pengabstraksian data hasil rekaman ditranskrip terlebih dahulu ke dalam bentuk wacana tulis, kemudian data tersebut dilakukan penganalisaan.

Salim (dalam Siregar, 2010: 213) menyebutkan ada tiga langkah penganalisaan data yaitu "reduksi data (data reduction), penyajian data (data display), dan penarikan kesimpulan (conclusion drawing)".

Data dalam peneletian kualitatif dapat dinyatakan valid apabila "tidak ada perbedaan antara apa yang dilaporkan oleh peneliti dengan apa yang sesungguhnya terjadi" (Siregar, 2010: 216). Uji keabsahan dalam penelitian ini meliputi uji kredibilitas (uji internal), uji dependability (reliabilitas), dan uji confirmability (Siregar, 2010).

\section{Hasil dan Pembahasan}

Penelitian ini dilakukan sesuai dengan prosedur penelitian yang telah dirancang sebelumnya. Sesuai dengan permasalahan penelitian yang dikemukakan dalam pendahuluan, uraian pada bagian ini dibedakan atas empat macam, yaitu (1) Identifikasi penggunaan ragam bahasa siswa dalam komunikasi verbal, (2) Pola interaksi siswa dengan guru dalam pembelajaran melalui penggunaan ragam bahasa, (3) Pola interaksi siswa dengan siswa dalam pembelajaran melalui penggunaan ragam bahasa, dan (4) Dampak pola interaksi siswa dalam pembelajaran melalui penggunaan ragam bahasa terhadap hasil belajar siswa. 
A. Identifikasi Penggunaan Ragam Bahasa Siswa dalam Komunikasi Verbal

Berdasarkan penelitian yang telah dilakukan di SD Negeri 4 Pedawa, ditemukan bentuk ragam bahasa dari segi keformalan dalam komunikasi di sekolah meliputi (1) ragam usaha atau ragam konsultatif, (2) ragam santai atau ragam kasual, dan (3) ragam akrab atau ragam intim yang bisa dilihat pada Tabel 1 berikut.

Tabel 1. Ragam Bahasa Siswa dalam Komunikasi Verbal di SD Negeri 4 Pedawa

\begin{tabular}{|c|c|c|c|c|c|c|}
\hline \multirow[b]{2}{*}{ Kelas } & \multicolumn{5}{|c|}{ Jumlah Tuturan Penggunaan Ragam Bahasa } & \multirow[b]{2}{*}{ Total } \\
\hline & $\begin{array}{c}\text { Ragam } \\
\text { Beku }\end{array}$ & $\begin{array}{l}\text { Ragam } \\
\text { Resmi }\end{array}$ & $\begin{array}{l}\text { Ragam } \\
\text { Usaha }\end{array}$ & $\begin{array}{l}\text { Ragam } \\
\text { Santai }\end{array}$ & $\begin{array}{l}\text { Ragam } \\
\text { Akrab }\end{array}$ & \\
\hline $\mathrm{I}$ & 3 & 1 & - & 3 & - & \\
\hline II & 1 & 10 & - & 8 & - & \\
\hline III & - & - & - & 5 & - & \\
\hline IV & 1 & 1 & - & 15 & - & \\
\hline V & 2 & 7 & - & 13 & 1 & \\
\hline VI & 2 & 4 & - & 6 & - & \\
\hline Jumlah & 9 & 23 & - & 50 & 1 & 83 \\
\hline Persentase & $11 \%$ & $28 \%$ & $0 \%$ & $60 \%$ & $1 \%$ & $100 \%$ \\
\hline
\end{tabular}

Berdasarkan Tabel tersebut, ragam bahasa santai lebih banyak digunakan oleh siswa dalam berkomunikasi di sekolah ketika saat pembelajaran. Hal ini terlihat dari jumlah tuturan pada ragam santai yaitu sebanyak 50 tuturan (60\%). Ragam bahasa terbanyak kedua yang digunakan siswa adalah ragam bahasa resmi Hal ini dapat dilihat dari jumlah tuturan siswa pada ragam resmi sebanyak 23 tuturan (28\%). Selanjutnya, ragam bahasa ketiga yang ditemukan adalah ragam beku. Ragam beku hampir sama dengan ragam resmi yang digunakan oleh siswa. Hal ini dapat dilihat dari jumlah tuturan pada ragam beku sebanyak 9 tuturan (11\%). Sedangkan ragam akrab hanya terjadi 1 tuturan yaitu di kelas $\mathrm{V}$.

Siswa kelas I yang belum memahami sekali penggunaan bahasa baku maupun bahasa formal karena baru mengenal lingkungan sekolah, sehingga bahasa yang mereka gunakan adalah bahasa ibu mereka yaitu bahasa Pedawa. Karena salah satu ciri ragam santai adalah lebih banyak bahasa pembicaraan penutur mengandung unsur bahasa daerah. Dibandingkan dengan siswa kelas tinggi yang sudah banyak menggunakan ragam usaha yaitu pembicaraan yang menggunakan bahasa semiformal atau bahasa Indonesia sehari-hari di sekolah. Pernyataan tersebut sejalan dengan pendapat Chaer dan Agustina (1995) yang menyatakan bahwa bahasa pertama seorang anak khususnya di Indonesia adalah bahasa daerahnya masing-masing, sedangkan bahasa Indonesia adalah bahasa kedua karena baru dipelajari ketika masuk sekolah, dan ketika dia sudah menguasai bahasa ibunya; kecuali mereka yang sejak bayi sudah mempelajari bahasa Indonesia dari ibunya. Penjelasan secara rinci mengenai penggunaan ragam bahasa siswa akan diuraikan sebagai berikut.

\section{1) Ragam Beku}

Ragam beku adalah variasi bahasa yang paling formal, yang digunakan dalam situasisituasi khidmat, dan upacara-upacara resmi, misalnya dalam upacara kenegaraan, khotbah di mesjid, tata cara pengambilan sumpah, akte notaris, dan surat-surat keputusan. Ragam baku yang diperoleh dalam penelitian ini adalah sebagai berikut.

(1) Konteks : Siswa menjawab pernyataan guru dengan lugas tentang hasil dari penjumlahan.

G : "Berarti kude adanē nē? Tujuh tambah dua puluh delapan kude dadinē?

G : 'Berarti berapa namanya ini? Tujuh tambah dua puluh delapan berapa hasilnya?'

$S$ : 'Tiga puluh lima.'

Percakapan tersebut terjadi antara guru dan siswa ketika pembelajaran berlangsung. Data tersebut menunjukkan ragam beku. Ragam beku tersebut ditandai dengan tuturan siswa yang menyebutkan angka ' 35 ' dengan pengucapan yang benar dan lengkap sesuai EYD yaitu 'tiga puluh lima'.

(2) Konteks : Siswa dengan kompak mengucapkan salam "Om Swastyastu" ketika ada guru lain masuk kelas.

S : "Om Swastyastu"

(Data 19)

Bahasa yang diujarkan siswa tersebut menunjukkan ragam beku. Ragam beku tersebut ditandai dengan tuturan siswa yang mengucapkan salam "Om Swastyastur". Salam ini yang 
dalam agama Hindu sekarang merupakan salam resmi dalam sidang-sidang Dewan Perwakilan maupun pertemuan resmi lainnya.

(3) Konteks : Siswa mengucapkan salam penutup setelah mengutarakan pendapatnya dan ditanggapi langsung oleh siswa lain dan guru.

S : "Om Santi, Santi Santi Om."

S dan G : "Om Santi, Santi Santi Om."

(Data 61)

Tuturan siswa tersebut menunjukkan ragam beku karena tuturan siswa tersebut merupakan salam penutup dalam agama Hindu yang sekarang merupakan salam resmi dalam sidang maupun pertemuan-pertemuan resmi.

\section{2) Ragam Resmi}

Ragam resmi atau formal adalah variasi bahasa yang digunakan dalam pidato kenegaraan, rapat dinas, surat-menyurat dinas, ceramah keagamaan, buku-buku pelajaran, dan sebagainya. Pola dan kaidah ragam resmi sudah ditetapkan secara mantap sebagai suatu standar. Ragam resmi yang diperoleh dalam penelitian ini adalah sebagai berikut.

(1) Konteks : Guru mulai membangun keaktifan siswa dengan menanyakan beberapa pertanyaan sederhana.

G :"Nah contoh, anak-anak baru bangun pagi, apakah yang anak-anak lakukan?"

S : "Merapikan tempat tidur."

(Data 10)

Data tersebut menjelaskan bahwa seorang siswa menyampaikan isi pesannya kepada guru. Data tersebut menunjukkan ragam resmi karena dalam ujaran tersebut terjadi pada situasi resmi yaitu ketika pembelajaran di kelas. Siswa mengucapkan "merapikan tempat tidur" yang dalam bahasa Indonesia sudah sesuai dengan EYD.

(2) Konteks : Siswa menanggapi penjelasan guru, tentang contoh cara menyapa jika bertemu dengan tamu yang datang ke sekolah.

$S$ : "Selamat pagi kak."

G: "Ya, selamat pagi kak."

(Data 14)

Data tersebut menjelaskan bahwa seorang siswa menyampaikan isi pesannya kepada guru. Data tersebut menunjukkan ragam resmi karena dalam ujaran tersebut terjadi pada situasi resmi yaitu ketika pembelajaran di kelas. Siswa mengucapkan salam "selamat pagi kak" yang dalam bahasa Indonesia sudah sesuai dengan EYD.

(3) Konteks : Seorang siswa menjawab pertanyaan guru sambil membaca buku.

G:"Kira-kira ada yang bisa menyebutkan arti koperasi anak-anak?"

S: "Kelompok atau perkumpulan orang untuk melakukan usaha bersama."

(Data 34)

Data tersebut menjelaskan bahwa seorang siswa menjawab pertanyaan guru sambil membaca buku. Data tersebut menunjukkan ragam resmi karena dalam ujaran tersebut terjadi pada situasi resmi yaitu ketika pembelajaran di kelas dan ujaran tersebut ada pada buku pelajaran siswa. Karena ragam resmi digunakan pada buku-buku pelajaran sekolah.

\section{3) Ragam Santai}

Ragam santai adalah variasi/ragam bahasa yang digunakan dalam situasi yang tidak resmi untuk berbincang-bincang dengan keluarga atau teman karib. Ragam santai banyak menggunakan bentuk alegro, yakni bentuk atau ujaran yang dipendekkan. Kosakatanya banyak dipenuhi oleh unsur leksial daerah dan unsur bahasa daerah serta banyak menngunakan kalimar elips, yaitu kalimat tidak sempurna yang bentuk dasarnya karena ada unsur-unsur yang hilang. Ragam santai atau kasual yang diperoleh dalam penelitian ini adalah sebagai berikut.

(1) Konteks : Seorang siswa bertanya kepada guru tentang koperasi pertanian dan ditanggapi langsung oleh gurunya.

$S$ : "Saje ada koperasi pertanian pak?"

G : "Nanti kegiatan usahanya ada yang menjurus ke pertanian."

(Data 39)

Data tersebut menjelaskan bahwa seorang siswa bertanya kepada guru. Data tersebut menunjukkan ragam santai karena dalam ujaran tersebut dipengaruhi oleh unsur bahasa daerah yaitu kata 'saje'. Kata 'saje' merupakan kata yang berasal dari bahasa bali yang berarti 'benarkah'. 
(2) Konteks : Seorang siswa mengungkapkan pendapatnya tentang peran koperasi produksi pada petani cengkeh.

G: "Kira-kira apa peran koperasi produksi pada petani cengkeh anak-anak?"

S : "Menyediakan banggul."

(Data 45)

Percakapan tersebut terjadi ketika siswa menyampaikan isi pesannya kepada guru. Tuturan tersebut menunjukkan ragam santai karena terdapat unsur bahasa daerah yaitu kata "banggul" yang berarti alat untuk mencari cengkeh di Desa Pedawa. Karena dalam ragam santai lebih banyak kosakatanya dipengaruhi unsur bahasa daerah. Tuturan data tersebut juga tidak perlu adanya perencanaan yang ekstensif tentang apa yang akan diungkapkan.

(3) Konteks : Seorang siswa bertanya kepada guru dan ditanggapi langsung oleh gurunya.

$\mathrm{S}$ : "Sayuran ade pak?"

S: 'Sayuran ada pak?'

G: "Kalau sayuran belum banyak anak-anak."

(Data 47)

Data tersebut mengungkapkan seorang siswa yang sedang bertanya kepada guru. Tuturan tersebut termasuk ke dalam ragam santai. Karena terdapat kosakata yang dipengaruhi dari unsur daerah, kosakata yang menunjukkan ragam santai yaitu kata "ade" yang biasa digunakan oleh masyarakat Bali yang berarti "ada".

4) Ragam Akrab

Ragam akrab adalah variasi bahasa yang biasa digunakan oleh para penutur yang hubungannya sudah akrab seperti antaranggota keluarga, atau antarteman yang sudah karib. Ragam ini ditandai dengan penggunaan bahasa yang tidak lengkap, pendek-pendek, dan dengan artikulasi yang seringkali tidak jelas. Ragam akrab atau intim yang diperoleh dalam penelitian ini adalah sebagai berikut.

(1) Konteks : Siswa menjawab dengan pelan pertanyaan guru.

G : "Terus waktunya apa yang temukan dalam sinetron tersebut?"

S: "Gak pak."

(Data 54)

Tuturan dari data tersebut menunjukkan seorang siswa menyampaikan isi pesannya dengan menjawab pertanyaan guru. Tuturan tersebut menunjukkan ragam akrab karena sudah ada hubungan yang saling pengertian antar penuturnya. Ragam akrab terlihat dari tuturan tersebut ketika penutur mengatakan "gak pak", hanya orang yang sudah saling paham yang mengerti dengan kalimat tersebut. Guru sebagai lawan tutur siswa sudah mengerti dengan ujaran siswanya tersebut. Pada ragam akrab ditandai dengan penggunaan bahasa yang tidak lengkap. Hal tersebut bisa dilihat pada tuturan tersebut, siswa hanya berujar "gak pak", yang "tidak Pak". Kata "gak" merupakan singkatan dari kata "tidak" yang digunakan oleh penutur yang mempunyai hubungan sudah akrab.

\section{B. Pola Interaksi Siswa Dengan Guru dalam Pembelajaran Melalui Penggunaan Ragam} Bahasa

Penjelasan secara rinci mengenai pola interaksi siswa dengan guru dalam pembelajaran melalui penggunaan ragam bahasa akan diuraikan sebagai berikut.

\section{1) Pola Interaksi Satu Arah}

Komunikasi sebagai aksi atau komunikasi satu arah menempatkan guru sebagai pemberi aksi dan siswa penerima aksi. Dalam hal pengunaan ragam bahasa, ketika guru menyampaikan pesan dengan salah satu ragam bahasa dan kemudian tidak ditanggapi oleh siswa juga disebut dengan komunikasi satu arah. Begitu juga ketika siswa berusaha menyampaikan pesan dengan suatu ragam bahasa, namun tidak ada tanggapan dari siswa lain maupun guru maka disebut juga dengan komunikasi satu arah.

(1) Konteks : Seorang siswa berusah memberitahu gurunya kalau dia sudah selesai mengerjakan soal.

S : "Sudah Buk."

(Data 4)

Tuturan tersebut terjadi ketika seorang siswa berusaha memberitahu gurunya jika dirinya sudah selesai mengerjakan tugas. Ujaran tersebut menunjukkan ragam santai. Pola interaksi yang terjadi adalah satu arah, karena ujaran siswa tersebut tidak mendapat tanggapan dari guru 
maupun dari siswa lain. Ketika penutur memberitahu ujarannya, lawan tuturnya tidak menanggapi dengan bentuk kata-kata maupun dalam bentuk gerak/isyarat.

(2) Konteks : Seorang siswa berusaha mengingatkan gurunya terkait buku tabungan siswa.

$\mathrm{S}$ : "Pak buku tabunganē pak!"

(Data 26)

Tuturan tersebut disampaikan oleh seorang siswa yang sedang mengingatkan gurunya tentang buku tabungan siswa. Tuturan tersebut menunjukkan ragam bahasa santai, karena terjadi pada situasi yang tidak resmi. Dalam tuturan siswa tersebut ada unsur bahasa daerah yaitu kata "tabunganē". Pola interaksi yang terjadi yaitu satu arah, karena tuturan tersebut tidak mendapat tanggapan dari guru maupun siswa lain.

\section{2) Pola Interaksi Dua Arah}

Komunikasi sebagai interaksi atau komunikasi dua arah guru berperan sebagai pemberi aksi atau penerima aksi, demikian pula halnya siswa bisa sebagai penerima aksi, bisa pula sebagai pemberi aksi. Antara guru dan siswa akan terjadi dialog di kelas maupun di luar kelas.

(1) Konteks : Ketika guru memberikan salam dan ditanggapi langsung oleh siswa.

\section{G : "Selamat pagi."}

S: "Pagi."

(Data 72)

Percakapan tersebut terjadi antara guru dan siswa. Percakapan tersbut menunjukkan ragam santai, karena siswa hanya menjawab singkat pertanyaan guru. Guru berusaha menyampaikan salam dan ditanggapi oleh semua siswa. Pola interaksi yang terjadi adalah dua arah, karena terjadi interaksi timbal balik antara guru dan siswa. Yangmana ketika guru menyapa siswa dengan ragam santai, siswa menanggapi dengan ragam santai pula yaitu dengan bahasa Indonesia.

(2) Konteks : Seorang siswa bertanya kepada guru apakah boleh menyimpulkan pembelajaran dari tempat duduknya.

$S$ : "Dari sini pak?"

G : "Ya silakan."

(Data 82)

Percakapan tersebut terjadi antara siswa dan guru ketika pembelajaran berlangsung yang menunjukkan ragam santai. Tuturan ragam santai tersebut dapat dilihat dari ujaran siswa yang tidak memperhatikan pengunaan kalimat seperti SPOK. Pola interaksi yang terjadi adalah dua arah, karena jelas sudah terjadi percakapan antara siswa dan guru. Ketika siswa bertanya menggunakan ragam santai, kemudian ditanggapi oleh guru menggunakan ragam santai juga.

3) Pola Interaksi Multi Arah

Komunikasi sebagai transaksi atau komunikasi multi arah, komunikasi tidak hanya terjadi antara guru dan siswa saja melainkan antar siswa. Dalam komunikasi multi arah ini, karena percakapan yang dilakukan antar siswa sehingga ragam bahasa yang digunakan lebih mengarah kepada ragam akrab.

(1) Konteks : Siswa mengucapkan salam sebelum menyampaikan pendapatnya dan ditanggapi oleh siswa yang lain.

S1: "Om Swastyastu"

S2 dan G: "Om Swastyastu"

(Data 59)

Percakapan tersebut terjadi antar siswa di dalam kelas. Data tersebut merupakan ragam beku, karena mengucapkan salam resmi. Pola interaksi yang terjadi adalah multi arah, karena terjadi komunikasi timbal balik antar siswa. Ketika seorang siswa mengucapkan salam, kemudian ditanggapi oleh siswa lain dengan mengucapkan salam pula.

C. Pola Interaksi Siswa dengan Siswa dalam Pembelajaran Melalui Penggunaan Ragam Bahasa

Penjelasan secara rinci mengenai pola interaksi siswa dengan siswa dalam pembelajaran melalui penggunaan ragam bahasa akan diuraikan sebagai berikut.

1) Pola Interaksi Satu Arah

Seperti yang sudah dijelaskan di awal bahwa pola interaksi/komunikasi satu arah hanya terjadi ketika si penutur menyampaikan ujarannya tidak mendapat tanggapan dari lawan tuturnya. Sehingga dalam komunikasi satu arah tidak ada suatu percakapan. Biasanya komunikasi satu arah ini terjadi ketika si penutur ingin menyampaikan isi perasaannya. 
(1) Konteks : Siswa dengan kompak mengucapkan salam "Om Swastyastu" ketika ada guru lain masuk kelas.

S : "Om Swastyastu"

(Data 19)

Bahasa yang diujarkan siswa tersebut menunjukkan ragam beku. Ragam beku tersebut ditandai dengan tuturan siswa yang mengucapkan salam "Om Swastyastui". Salam ini yang dalam agama Hindu sekarang merupakan salam resmi dalam sidang-sidang Dewan Perwakilan maupun pertemuan resmi lainnya. Pola interaksi yang terjadi adalah satu arah, karena tidak ada tanggapan dari guru.

(2) Konteks : Seorang siswa mengungkapkan bahwa jawaban dirinya adalah "b". $S$ : "Buk, 'b' aku."

(Data 27)

Bahasa yang diujarkan siswa tersebut menunjukkan ragam santai. Ragam santai tersebut ditandai dengan tuturan siswa yang tidak memperhatikan penggunaan kalimat dengan benar seperti SPOK. Pola interaksi yang terjadi adalah satu arah, karena tidak ada tanggapan dari guru.

2) Pola Interaksi Dua Arah

Komunikasi sebagai interaksi atau komunikasi dua arah guru berperan sebagai pemberi aksi atau penerima aksi, demikian pula halnya siswa bisa sebagai penerima aksi, bisa pula sebagai pemberi aksi. Antara guru dan siswa akan terjadi dialog di kelas maupun di luar kelas.

(1) Konteks : Beberapa siswa menjawab dengan lugas pertanyaan guru tentang bahan yang diperlukan suatu koperasi.

G : "Misalnya kira-kira disini apa yang diperlukan?"

S1: Cangkul,

S2: Beras,

S3: Pupuk,

S4: Buku.

(Data 38)

Percakapan tersebut terjadi antara guru dan siswa. Percakapan tersbut menunjukkan ragam santai, karena siswa hanya menjawab singkat pertanyaan guru. Pola interaksi yang terjadi adalah dua arah, karena terjadi interaksi timbal balik antara guru dan siswa. Yangmana ketika guru bertanya dengan ragam santai, siswa menanggapi dengan ragam santai pula yaitu dengan bahasa Indonesia.

\section{3) Pola Interaksi Multi Arah}

Komunikasi sebagai transaksi atau komunikasi multi arah, komunikasi tidak hanya terjadi antara guru dan siswa saja melainkan antar siswa. Dalam komunikasi multi arah ini, karena percakapan yang dilakukan antar siswa sehingga ragam bahasa yang digunakan lebih mengarah kepada ragam akrab. Hal ini sesuai dengan hasil wawancara kepada guru SD Negeri 4 Pedawa, jika terjadi komunikasi antar siswa akan lebih banyak menggunakan bahasa daerah maupun bahasa mereka sendiri-sendiri yang dalam ragam bahasa disebut ragam santai mapaun ragam akrab, karena sudah ada hubungan saling pengertian antar penutur.

(1) Konteks : Siswa mengucapkan salam penutup setelah mengutarakan pendapatnya dan ditanggapi langsung oleh siswa lain dan guru.

S: "Om Santi, Santi Santi Om."

S dan G : "Om Santi, Santi Santi Om."

(Data 61)

Tuturan siswa tersebut menunjukkan ragam beku karena tuturan siswa tersebut merupakan salam penutup dalam agama Hindu yang sekarang merupakan salam resmi dalam sidang maupun pertemuan-pertemuan resmi. Pola interaksi yang terjadi adalah multi arah, karena terjadi komunikasi timbal balik antar siswa. Ketika penutur meberikan stimulus dengan ragam beku, kemudian ditanggapi oleh lawan tutur dengan bahasa beku pula.

Dari penjelasan yang sudah dipaparkan terkait pola interaksi yang terjadi dalam pembelajaran ditemukan adanya pola interaksi satu arah, pola interaksi dua arah (guru dengan siswa), dan pola interaksi multi arah (siswa dengan siswa). Hal ini sejalan dengan pendapat Djamarah (2000) yang menyatakan bahwa interaksi yang biasanya terjadi di dalam kelas adalah interaksi antara guru dengan siswa dan interaksi antara siswa dengan siswa ketika pelajaran berlangsung. Namun, kenyataannya di lapangan pola interaksi satu arah juga bisa terjadi ketika pembelajaran berlangsung. Pola interaksi satu arah ini terjadi ketika ujaran siswa 
tidak mendapat tanggapan dari guru maupun dari siswa lain. Begitu juga dengan guru, ketika memberikan informasi kepada siswa, mereka tidak memberikan tanggapan. Ketika guru mulai menjelaskan, siswa hanya diam dan memperhatikan.

4) Dampak Pola Interaksi Siswa Dalam Pembelajaran Melalui Penggunaan Ragam Bahasa Terhadap Hasil Belajar Siswa

Berdasarkan penelitian yang dilakukan di SD Negeri 4 Pedawa, ditemukan hasil belajar siswa yang beragam seperti pada tabel 2 berikut.

Tabel 2. Daftar Pencapaian Ketuntasan Hasil Belajar Siswa SD Negeri 4 Pedawa

\begin{tabular}{clccccccc}
\hline \multirow{2}{*}{$\begin{array}{c}\text { Kel } \\
\text { as }\end{array}$} & Mata Pelajaran & \multicolumn{3}{c}{ Pola Interaksi } & \multicolumn{2}{c}{$\begin{array}{c}\text { Siswa Mencapai } \\
\text { KKM }\end{array}$} & \multicolumn{2}{c}{$\begin{array}{c}\text { Siswa Belum } \\
\text { Mencapai KKM }\end{array}$} \\
\cline { 3 - 8 } & & $\begin{array}{c}\text { Satu } \\
\text { Arah }\end{array}$ & $\begin{array}{c}\text { Dua } \\
\text { Arah }\end{array}$ & $\begin{array}{c}\text { Multi } \\
\text { Arah }\end{array}$ & $\%$ & Siswa & $\%$ & Siswa \\
\hline I & Matematika & 1 & 6 & - & $86 \%$ & 12 & $14 \%$ & 2 \\
II & Budi Pekerti & 2 & 17 & - & $93 \%$ & 13 & $7 \%$ & 1 \\
III & IPA & 2 & 3 & - & $80 \%$ & 12 & $20 \%$ & 3 \\
IV & IPS & 1 & 16 & - & $75 \%$ & 6 & $25 \%$ & 2 \\
V & Bahasa Indonesia & 2 & 19 & 2 & $67 \%$ & 10 & $33 \%$ & 5 \\
VI & IPA & - & 12 & - & $82 \%$ & 14 & $18 \%$ & 3 \\
\hline
\end{tabular}

Dari hasil penelitian yang dilakukan di SD Negeri 4 Pedawa tentang dampak pola interaksi siswa dalam pembelajaran melalui penggunaan ragam bahasa terhadap hasil belajar siswa, ditemukan keragaman dalam nilai siswa yang diambil dari nilai ulangan harian siswa kelas $1 \mathrm{~s} . d$ kelas 6 sesuai dengan mata pelajaran yang diteliti ketika pengambilan data. Dari persentase siswa yang sudah mampu mencapai KKM dan siswa yang belum mampu mencapai KKM dapat dibuktikan bahwa hasil belajar siswa dapat diengaruhi oleh ragam bahasa yang digunakan siswa dan guru dalam kegiatan pembelajaran. Menurut Chaer dan Agustina (1995) menyatakan dalam masyarakat yang multilingual, multirasial, dan multicultural, maka faktor kebahasaan merupakan variable yang dapat mempengaruhi keberhasilan belajar siswa. Umpamanya, siswa yang sehari-hari di rumah dan di lungkungan masyarakat menggunakan bahasa Indonesia, tentu akan mempunyai kemungkinan untuk lebih berhasil dalam pelajaran bahasa Indonesia daripada siswa yang tinggal dalam keluarga dan lingkungan masyarakat yang tidak menggunakan bahasa Indonesia. Demikian juga siswa akan lebih berhasil dalam belajar bahasa Indonesia apabila orang-orang yang terlibat dalam lingkungan sekolah (guru, pegawai, dan lain-lain) dalam percakapan sehari-hari menggunakan bahasa Indonesia daripada yang tidak berbahasa Indonesia.

Terlihat bahwa di setiap kelas hampir terjadi pola interaksi satu arah, dua arah, dan multi arah. Pola interaksi yang paling banyak terjadi di setiap kelas adalah pola interaksi dua arah yang mana pada pola interaksi dua arah terjadi timbal balik antara guru dengan siswa. Pola interaksi multi arah sedikit terjadi karena hampir di setiap kelas guru tidak ada menggunakan metode kerja kelompok. Guru dalam mengajar hanya memberikan penjelasan secara lisan. Namun demikin, hasil belajar siswa di setiap kelas lebih banyak siswa yang sudah mencapai KKM daripada siswa yang belum mencapai KKM. Berarti, pola interaksi dua arah dapat membantu siswa untuk mencapai hasil belajar yang baik, karena melalui pola interaksi tersebut siswa akan mendapatkan lebih banyak ilmu ketimbang hanya terjadi pola interaksi satu arah, karena tidak ada interaksi timbal balik antar siswa maupun dengan guru. Hal tersebut sejalan dengan pendapat Majid (2013:289) yang menyatakan bahwa komunikasi yang dianggap efektif adalah komunikasi yang menimbulkan arus informasi dua arah, bahkan multi arah, yaitu dengan munculnya feedback dari penerima pesan.

\section{Simpulan dan Saran}

Berdasarkan pembahasan yang telah dijabarkan pada bab sebelumnya, maka dapat diambil kesimpulan yaitu, (1) Bentuk ragam bahasa dari segi keformalan dapat diidentifikasikan terdapat empat ragam bahasa dalam komunikasi verbal siswa SD Negeri 4 Pedawa yaitu ragam beku yang digunakan sebanyak 9 tuturan (11\%), ragam resmi sebanyak 23 tuturan (28\%), ragam santai sebanyak 50 tuturan (60\%), dan ragam akrab sebanyak 1 tuturan (1\%)., (2) Pola interaksi yang terjadi antara siswa dengan guru dalam pembelajaran melalui 
penggunaan ragam bahasa yaitu komunikasi satu arah, dua arah, dan multi arah, (3) Pola interaksi yang terjadi antara siswa dengan siswa dalam pembelajaran melalui penggunaan ragam bahasa yaitu komunikasi satu arah, dua arah, dan multi arah, dan (4) Dampak pola interaksi siswa dalam penggunaan ragam bahasa terhadap hasil belajar siswa sangat beragam, yangmana terdapat siswa yang sudah mencapai KKM dan ada siswa yang belum mencapai KKM.

Saran yang dapat disampaikan berdasarkan penelitian yang telah dilakukan adalah (1) Guru hendaknya harus dapat menggunakan variasi bahasa yang sesuai dengan tingkat kognitif siswa agar hasil belajar yang diperoleh siswa baik sehingga tujuan pembelajaran dapat tercapai, (2) Siswa hendaknya mampu mengikuti kegiatan pembelajaran yang berlangsung di kelas dengan baik dan aktif dengan memperhatikan pola interaksi kepada guru maupun siswa lain, dan (3) Penelitian ini hanya mengkaji ragam bahasa dari segi keformalan dan pola interaksi siswa yang terjadi, sehingga diharapkan penelitian selanjutnya dapat dilakukan penelitian tentang ragam bahasa dari segi yang lain, misalnya ragam bahasa dari segi penuturnya.

\section{Daftar Pustaka}

Agustina, Sinta, dkk. 2015. "Analisis Penggunaan Bahasa Alay Dalam Kosakata Bahasa Indonesia Siswa Sekolah Dasar". Penelitian. Jurusan Pendidikan Guru Sekolah Dasar, Fakultas IImu Pendidikan, Universitas Pendidikan Indonesia Kampus Tasikmalaya.

Apriastuti, Ayu Ari. 2017. "Bentuk, Fungsi Dan Jenis Tindak Tutur Dalam Komunikasi Siswa di Kelas IX Unggulan SMP PGRI 3 Denpasar". Jurnal IImiah Pendidikan dan Pembelajaran. Vol. 14, No. 1 (hlm. 38-47).

Chaer, Abdul dan Leonie Agustina. 1995. Sosiolinguistik: Perkenalan Awal. Jakarta: Rineka Cipta.

Dantes, Nyoman. 2012. Metode Penelitian. Yogyakarta: Andi.

Djamarah, Syiful Bahri. 2000. Guru dan Anak Didik Dalam Interaksi Edukatif. Jakarta: Rineka Cipta.

Kurniawati. 2009. "Pengaruh Prestise Lokasi Tuturan Terhadap Ragam Bahasa Remaja Puteri Dalam Percakapan Informal”. Jurnal Pendidikan Dasar.. Vol. 1, No. 1.

Majid, Abdul. 2013. Strategi Pembelajaran. Bandung: Pt Remaja Rosdakarya.

Siregar, Syofian. 2010. Statistika Deskriptif untuk Penelitian. Jakarta: RajaGrafindo Persada.

Sudaryati, Sri. 2018. "Variasi Keformalan Dalam Wacana Kelas Mahasiswa Angkatan 2016 Kelas A Program Studi Pendidikan Bahasa Indonesia Universitas Tadulako". Jurnal. Vol. 3 No. 5.

Sumarlam, dkk. 2012. Pelangi Nusantara: Kajian Berbagai Variasi Bahasa. Yogyakarta: Graha IImu.

Yulia, Nova. 2013. "Ragam Bahasa Anak-anak: Ditinjau dari Segi Sosiolinguistik". Lingua Didaktika. Vol. 6. No. 2 (hlm. 109-119). 